\title{
Extrusão tectônica e transporte lateral de massa na porção central do cinturão Paraíba do Sul, seção Três Rios - Matias Barbosa (RJ/MG)
}

\author{
Letícia Constantino Vicente ${ }^{1}$, Nolan Maia Dehler ${ }^{2}$, Rômulo Machado ${ }^{3}$ \& Tiago da Rocha Karniol ${ }^{1}$
}

\begin{abstract}
Resumo Este trabalho discute a estrutura de uma seção no flanco norte da divergência estrutural do vale do rio Paraíba do Sul no Rio de Janeiro. No centro da estrutura, a foliação milonítica é vertical, a lineação de estiramento é horizontal e os indicadores cinemáticos sugerem movimentação destral (Domínio I). O estiramento vertical é secundário, e o encurtamento ortogonal ao plano de fluxo é evidenciado por estruturas em forma de tablete-de-chocolate. Para norte, ocorre um fragmento crustal (lasca tectônica) composto principalmente por ortognaisse (Domínio Paraíba do Sul - Domínio II). Este fragmento sobrepõe-se aos granulitos do Domínio Juiz de Fora (Domínio III). Ocorrem associadas à foliação principal dobras apertadas a isoclinais com eixos subparalelos a lineação de estiramento, além de dobras com superfície axial íngreme subparalelas às zonas de cisalhamento transpressivas e eixos paralelos à lineação de estiramento, que deformam a foliação milonítica. São encontrados tectonitos L e mullions subparalelos às charneiras dos dois grupos de dobras. No Domínio II, a foliação principal delineia em estereograma uma guirlanda com eixo de caimento baixo para NE, que é subparalelo a concentração da lineação de estiramento. Os indicadores cinemáticos sugerem movimento de topo para WSW, subparalelos e oblíquos ao cinturão Paraíba do Sul. A foliação e a lineação de estiramento apresentam orientação semelhante nos domínios II e III. Nos granulitos, estas estruturas obliteram a estruturação anterior. São registradas estruturas tardias, como zonas de cisalhamento dúcteis-rúpteis inversas com movimentação de topo para NW, e zonas de cisalhamento dúcteis transtrativas, sinistrais. A evolução estrutural (principal e tardia) da área é interpretada em termos de uma transpressão não-confinada. A partição da deformação durante convergência oblíqua e extrusão tectônica poderia explicar a simultaneidade entre os movimentos paralelos ao cinturão e os empurrões destrais para NW. A extrusão tectônica poderia explicar também a geração de tectonitos L e a ausência de lineações verticais nas zonas de cisalhamento transpressivas do cinturão.
\end{abstract}

Palavras-Chave: Cinemática, Transpressão, Extrusão, Cinturão Paraíba do Sul.

Abstract Tectonic extrusion and lateral mass transport in the inner portion of Paraiba do Sul belt, Três Rios - Matias Barbosa (MJ/MG) cross-section. This paper deals with the geometry and kinematics of structures, described along a section cross-cutting the northern limb of a NE-trending regional fan-like geometry. The structure occurs on the core of the Ribeira orogen in SE Brazil. Three structural domains were described, from south to north. In the domain I, the mylonitic foliation runs towards NE with sub-vertical to vertical dip. Stretching lineation is horizontal, and assymmetric structures suggest dextral transpressive motion in the core of the divergence (domain I). Tablet-of-chocolate boudinage suggests secondary vertical stretching and shortening orthogonal to the flow plane occurs. Northwards occurs a crustal slice composed mainly by orthogneiss, and minor metassediments and deformed granitoids, called Paraíba do Sul domain - or domain II. This slice tectonically overlies the granulitic rocks of the Juiz de Fora domain (domain III). Foliation in domain II delineates a guirdle on the stereoplot, with slowly ENE- plunging axes. Stretching lineation plunges slowly to $\mathrm{NE}$, parallel to the girdle axes. Tight to isoclinal folds with axis parallel to the stretching lineation occur within the mylonitic foliation. Slowly southward dipping mylonitic foliation (and associated folds) are deformed by open to tight, nearly upright extension-parallel folds with axial surfaces sub-parallel to the regional transpression zones. L-tectonites in deformed granitoids, and mullion structures parallel to the axes of both families of folds also were described. Shear-sense indicators suggest top-to-SWW shearing, sub-parallel and oblique to the orogenic trend, coeval with a NW-SE contractional component. Later structures are ductile-ruptile top-toNW thrusts and sinistral transtrative shear zones. The structural evolution of the area is interpreted in terms of regional dextral unconfined transpression. Our observations suggest that strain path partitioning during oblique extrusion and convergence may explain coeval parallel orogenic motion either in flat lying or steeply dipping shear zones, and WNW-directed dextral thrusts described in the deeper portions of the belt. Tectonic extrusion may also explain the presence of L-tectonites and the absence of vertical stretching lineation in the highly strained zones in the Paraíba do Sul Belt.

Keywords: kinematics, transpression, tectonic extrusion, Paraíba do Sul Belt.

1 - Pós-Graduação, Instituto de Geociências, USP, São Paulo, SP, Brasil. E-mail: lcvicente@usp.br, tikarniol@yahoo.com

2 - PETROBRAS, Rio de Janeiro, RJ, Brasil. E-mail: nolan@petrobras.com.br

3 - Instituto de Geociências, Universidade de São Paulo, São Paulo, SP, Brasil. E-mail: rmachado@usp.br 
INTRODUÇÃO A divergência estrutural do vale do rio Paraíba do Sul é uma estrutura regional em leque com direção NE que possui dois flancos, um a norte da zona de cisalhamento de Além-Paraíba, e outro a sul desta zona. Nos dois flancos da estrutura são encontrados milonitos que mergulham em direção à zona de cisalhamento. Esta estrutura tem sido descrita como uma estrutura transpressiva, desenvolvida em condições metamórficas de alto grau.

O estudo da tectônica do Cinturão Paraíba do Sul (CPS) - domínio central da Província Mantiqueira (sensu Hasui \& Oliveira 1984) - foi iniciado no final da segunda metade do século passado, com os trabalhos pioneiros sendo desenvolvidos principalmente por Rosier $(1957,1965)$ e Ebert $(1956,1968)$. Estes autores propuseram um modelo tectônico caracterizado por empurrões e nappes transportados para NW, presentes tanto nas porções internas do cinturão como mais para norte em direção ao antepaís (representado pelo Craton do São Francisco). Numa ótica mais atualística, este antepaís estaria contido na denominada Placa SanFranciscana (PSF) (Alkmin et al. 1993) (Fig. 1).

Os modelos estruturais disponíveis para a região hierarquizam as estruturas formadas durante a movimentação geral para norte em diferentes estágios na evolução tectônica do cinturão: (1) como estruturas precoces, $\mathrm{D}_{1}$ e $\mathrm{D}_{2}$ ou $\mathrm{F}_{1}$ e $\mathrm{F}_{2}$, que seriam anteriores aos movimentos transcorrentes, considerados tardios (ver Heilbron et al. 1995, dentre outros), (2) como estruturas não necessariamente mais antigas do que as transcorrências, podendo ser consideradas mesmo contemporâneas, pois, do ponto de vista geométrico e cinemático, apresentam um movimento coerente no âmbito de uma megaestrutura-em-flor positiva, relacionada com um regime transpressivo regional (Machado \& Endo1993 a e b, Ebert et al. 1993, dentre outros).

$\mathrm{O}$ grupo de estruturas compressivas tem sido associado, independentemente do modelo adotado, à deformação orogênica principal do cinturão (a exemplo do que foi proposto originalmente por Ebert). Fica evidente então que um dos aspectos fundamentais nesta questão, e que diferencia também os modelos propostos, é a interpretação do significado tectônico das estruturas de baixo ângulo, compressivas, e com movimentação de topo-para-NW. A caracterização de zonas de cisalhamento de baixo ângulo, associadas a movimentos oblíquos e subparalelos ao cinturão na região, evidencia a necessidade de uma reavaliação dos modelos tectônicos disponíveis (ver Ebert \& Hasui 1998, Dehler 2002 e Dehler \& Machado 2002).

São apresentados e discutidos neste trabalho os dados estruturais levantados em uma seção ao longo da BR-040, entre as cidades de Três Rios (RJ) e Matias Barbosa (MG), segmento este que corta quase ortogonalmente a aba norte da estrutura divergente do rio Paraíba do Sul. Os resultados obtidos apontam para um modelo tectônico de extrusão oblíqua vinculado regionalmente a uma movimentação destral do cinturão, em regime transpressivo, não-confinado.

\section{O CINTURÃo PARAÍbA do SUL NO RIO DE} JANEIRO $O$ arcabouço estrutural do cinturão Paraíba do Sul (na concepção de Ebert 1968, 1972), ou da faixa Ribeira (na concepção de Almeida 1973), localizado a SE de uma região menos deformada, denominada Craton do São Francisco, é dado por um arranjo estrutural de direção geral NE de zonas de cisalhamento contracionais Neoproterozóicas (Heilbron et al. 2004) (Fig. 2). Nas porções internas do cinturão, ocorre uma inversão regional que confere uma geometria sinclinorial assimétrica, denominada estrutura divergente ou divergência-em-leque do rio Paraíba do Sul (ver Ebert 1968 e Machado 1983). Constitui-se num arranjo divergente regional, formando um leque assimétrico de zonas de cisalhamento e plano axial de dobras, associado a movimentos ativos em condições metamórficas de alto grau (ver também Heilbron et al. 1991, Machado \& Endo 1993 a).

No flanco norte da estrutura ocorrem zonas contracionais com direção geral NE e mergulhos variados para SE, com movimentação frontal a oblíqua de topo para NW, em direção ao Craton do São Francisco (Heilbron 1993, Almeida 2001). No centro da estrutura ocorrem faixas de cisalhamento transpressivas, destrais (Dayan \& Keller 1989, Ebert et al. 1991, Dayan et al. 1993). A principal estrutura da região é a Zona de Cisalhamento de Além Paraíba (Almeida et al. 1975). A sul desta estrutura ocorre uma outra zona de cisalhamento (Zona de Cisalhamento Rio Santana-Ribeirão das Lajes) com foliação milonítica mergulhando para noroeste, associada à movimentação de topo para SW, seguida de deslocamento transtrativo destral e empurrões mais tardios com movimento de topo para SE (Machado 1983, Dehler et al. 2006).

Os modelos estruturais disponíveis na literatura para explicar a formação desta importante feição estrutural englobam concepções distintas, quais sejam: uma geométrica, num contexto de evolução tectônica polifásica, onde a estrutura divergente é considerada como uma mega-dobra tardia, com superfície axial vertical e eixo com caimento para NE, que deformaria as zonas de cisalhamento anteriores com movimentação de topo-para-NW (Heilbron et al. 1991, Almeida 2000); e outra envolvendo conceitos da tectônica transpressiva, onde a estrutura divergente representaria uma megaestrutura-em-flor positiva, cuja parte central seria ocupada pela Zona de Cisalhamento Dúctil de Além-Paraíba (Machado \& Endo 1993 a e b, Corrêa Neto et al. 1993, Dayan et al. 1993).

Os trabalhos sistemáticos de Ebert, realizados na região SE de Minas Gerais e região limítrofe com o Rio de Janeiro (sintetizados em Ebert 1956, 1968 e 1984), identificaram um sistema de empurrões e dobras com vergência para NW, considerados responsáveis pela estruturação principal do CPS na região (ver também Rosier 1957). Posteriormente, trabalhos baseados na análise geométrica regional das estruturas sugeriram um modelo tectônico polifásico para a estruturação principal do cinturão, onde as estruturas mais antigas $\left(D_{1}\right.$ e $\left.D_{2}\right)$ são associadas a movimentos compressivos 


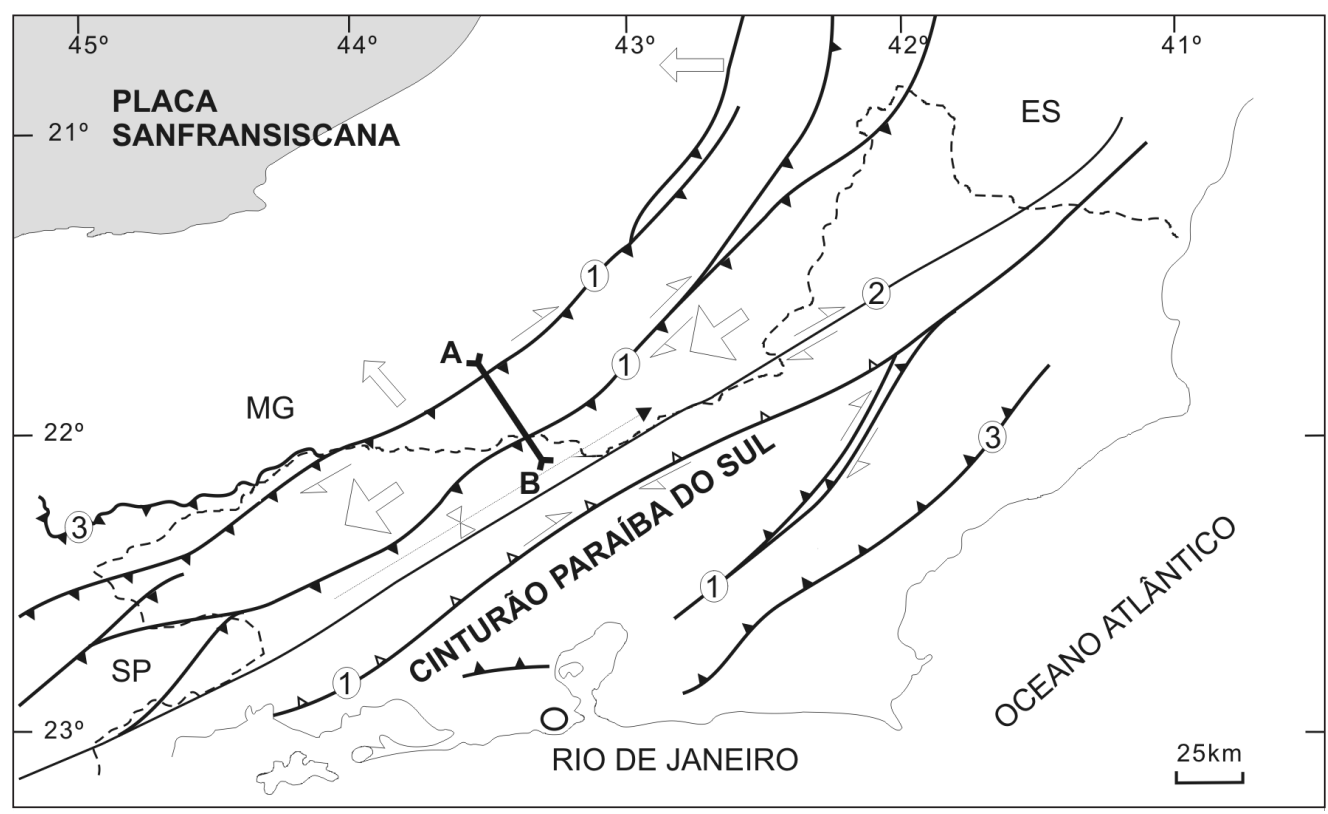

Figura 1 - Esboço estrutural do Cinturão Paraíba do Sul (CPS) no Estado do Rio de Janeiro e localização da Seção lito-estrutural levantada (A-B). Legenda: Seta maior- fluxo de deformação principal; Seta menor - fluxo de deformação secundário; (1) Zona de cisalhamento oblíqua com movimento indicado; (2) Zona de cisalhamento direcional com movimento indicado; (3) Zona de cisalhamento inversa (Modificado de Machado \&Demange 1994 e Silva et al. 2000).

correlatos àqueles propostos por Ebert (ver Machado 1983 e 1984, Heilbron 1993). A fase principal teria originado estruturas de baixo ângulo com vergência para NW, e seria também responsável pelo arcabouço tectônico regional (Heilbron et al. 1995). As estruturas tardias (atribuídas a uma terceira fase de deformação regional) seriam responsáveis pela geração de dobras abertas a cerradas com planos axiais verticais e eixos subhorizontais (Campanha 1981), bem como por zonas de cisalhamento dúcteis desenvolvidas sob condições metamórficas de alto grau e em regime transcorrente/ transpressivo destral (Braun 1972, comunicação oral).

Após a caracterização da transpressão destral em condições metamórficas de alto grau nas zonas de cisalhamento regionais (Dayan \& Keller 1989, Ebert et al. 1991, Corrêa Neto et al. 1993, Egydio-Silva et al. 2004), alguns autores propuseram o desenvolvimento contemporâneo entre as estruturas de baixo e de alto ângulo (Machado \& Endo 1993 a). Neste modelo tectônico - modelo de transpressão -, a contemporaneidade entre as zonas de cisalhamento de baixo e de alto ângulo implica numa articulação cinemática e partição da deformação, sob condições de convergência oblíqua, envolvendo componentes de encurtamento transversal e de cisalhamento simples paralelo ao CPS (Ebert et al. 1993b, Ebert \& Hasui 1998). Dehler \& Machado (2002), estudando o flanco sul da estrutura divergente, sugerem que o desenvolvimento das estruturas precoces teria ocorrido durante movimentação de topo para SSW, sob condições metamórficas de alto grau e concomitante com uma expressiva anatexia crustal no CPS. Consideram ainda que as estruturas precoces são associadas à extrusão tectônica para SSW de uma cros- ta continental parcialmente fundida. Estas estruturas foram superpostas por zonas de cisalhamento dúcteis transpressivas destrais, dobras e zonas de cisalhamento inversas, que teriam sido ativas durante o resfriamento e soerguimento progressivo do CPS na região (Dehler 2002). Sínteses regionais recentes sobre a evolução estrutural e tectônica do CPS a SE do CSF são encontradas em Trouw et al. (2000) e Heilbron et al. (2004).

APRESENTAÇÃO DOS DADOS Os dados geométricos e cinemáticos, levantados ao longo da seção ortogonal ao flanco norte da estrutura divergente regional serão descritos a seguir de sul para norte (ver Figs. 1 e 2). Os dados foram agrupados em domínios estruturais homogêneos e serão discutidos quanto à orientação de um elemento estrutural específico (Turner \& Weiss 1963).

Para definição desses domínios, adotou-se como critério o comportamento da foliação principal, uma vez que a lineação de estiramento e mineral não mostra variações significativas ao longo da seção. Os dados estruturais são apresentados em diagramas de Schimdt-Lambert, hemisfério inferior. Os indicadores cinemáticos foram descritos em seções paralelas à lineação de estiramento e ortogonais à foliação (seções paralelas ao plano XZ do elipsóide de deformação finita - ver Simpson \& Schmid 1983, Hanmer \& Passchier 1991).

Foram identificados três domínios estruturais ao longo da seção estudada (Fig. 2). O Domínio Estrutural I (DE I), localizado na parte sul da seção, é caracterizado por uma foliação milonítica vertical de direção NE-SW e uma lineação de estiramento direcional. O Domínio 


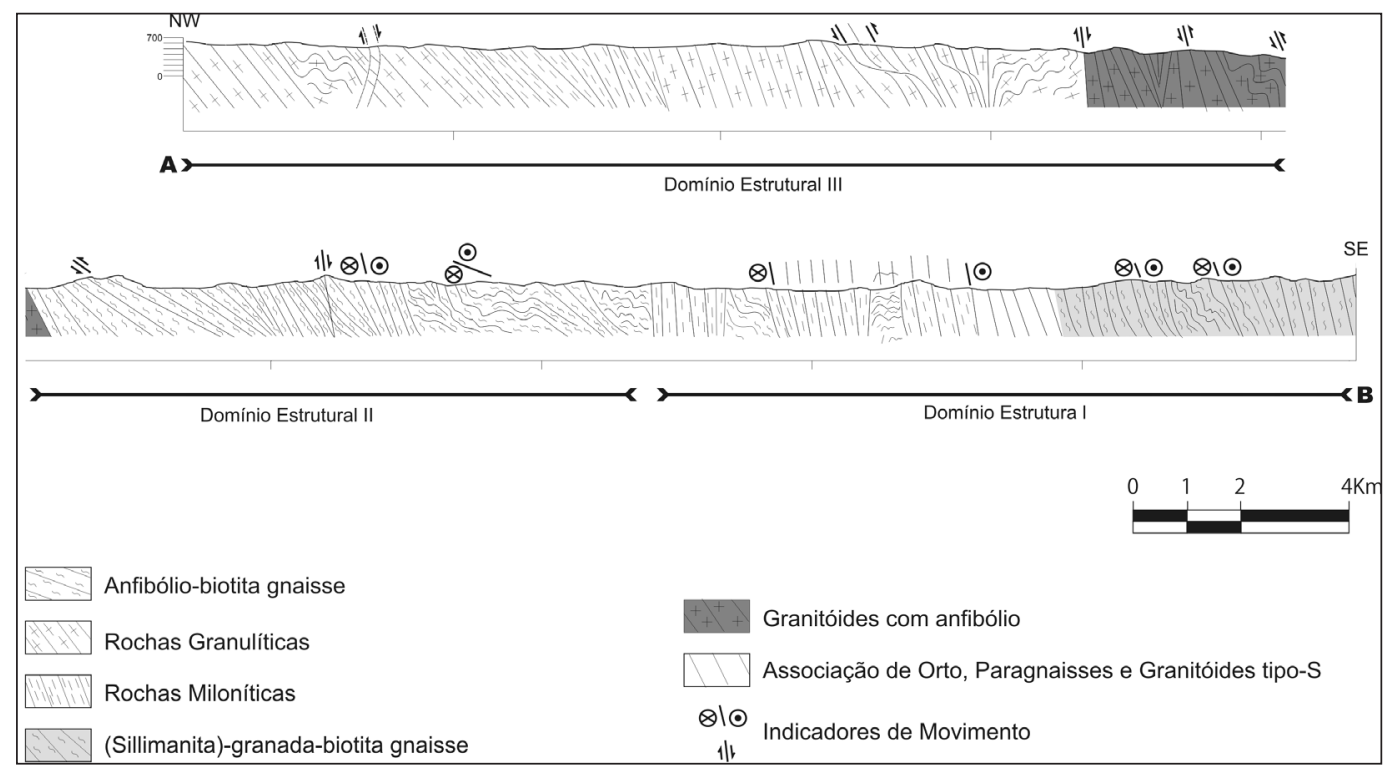

Figura 2 - Seção lito-estrutural entre Três Rios - Matias Barbosa (STMB). Ver discussão no texto.

Estrutural II (DE II), localizado na porção intermediária da seção, é caracterizado por uma foliação gnáissica e milonítica, com mergulho variável preferencialmente para SE, contendo uma lineação de estiramento mineral de caimento baixo para ENE. O Domínio Estrutural III (DE III), situado na porção norte da seção, caracterizase por foliação com mergulho moderado a alto para SE e lineação de estiramento mineral oblíqua, com caimento baixo para NE.

Domínio Estrutural I O Domínio Estrutural I (DE I) compreende uma associação de (anfibólio)-biotita ortognaisse, paragnaisses e granitóides, que foi influenciado pela Zona de Cisalhamento de Além-Paraíba (Fig. 2 - ver Almeida et al. 1975). As texturas e estruturas das rochas deste domínio são tipicamente miloníticas (ver também Dayan \& Keller 1989, Corrêa Neto et al. 1993, Egydio-Silva \& Mainprice 1999). Ocorrem ainda inclusões tectônicas de orto-granulitos nos milonitos ao longo do eixo principal da referida zona de cisalhamento.

As rochas do domínio apresentam em geral uma trama planar bem desenvolvida. A foliação milonítica é definida pela orientação preferencial de minerais estirados e recristalizados como biotita, feldspato, quartzo, anfibólio e sillimanita. Nas regiões mais deformadas, a foliação mostra-se paralela a um bandamento deformacional ou laminação tectônica, materializada por intercalações de bandas félsicas e máficas. Os minerais destas bandas apresentam granulação média a fina, principalmente nos níveis máficos. Ocorrem porções de granulação grossa, relativamente mais preservadas da deformação, formando pods ou bandas de composição granítica. Nos ortognaisses miloníticos observam-se também bandas com porfiroclastos estirados de feldspato (K-feldspato e plagioclásio). Em lâmina delgada, o K-feldspato mostra-se deformado e recristalizado (poligonizado). O plagioclásio exibe evidências de deformação plástica ou ruptura das maclas polissintéticas, bem como recristalização e poligonização nas suas bordas ou no interior dos porfiroclastos. O quartzo encontrase em geral poligonizado, exibindo ou não evidências de deformação. No primeiro caso mostra extinção ondulante e crescimento exagerado dos cristais, englobando muitas vezes cristais menores orientados da matriz. Ocorrem ainda microestruturas como ribbons de quartzo e K-feldspato (microclínio). Os anfibólios desses milonitos apresentam feições microestruturais sugestivas de deformação dúctil em fácies granulito (Egydio Silva et al. 2004).

Nas porções de deformação mais elevada, as bandas são contínuas por extensão métrica, conferindo aos gnaisses miloníticos um marcante aspecto listrado, com a estrutura sendo realçada pela presença de enclaves e/ou boudins de rochas cálciossilicáticas e anfibolitos alinhados, fortemente estirados e achatados no plano da foliação. Em projeção estereográfica, a foliação milonítica exibe concentração máxima dos pólos nos quadrantes NNW e SSE, resultando direção estatística N66 ${ }^{\circ} \mathrm{E}$, com mergulho subvertical (Fig. 3A).

A lineação de estiramento e mineral é em geral bem marcada no DE I, com exceção de locais onde a trama planar predomina em relação à trama linear (Stectonitos). A lineação é conferida pela orientação preferencial de feldspato, quartzo, anfibólio, biotita, sillimanita ou de agregados destes minerais. Esta estrutura é conferida também pela orientação do eixo maior de inclusões de cálciossilicáticas e anfibolitos. Em projeção estereográfica, a lineação tem orientação NE-SW

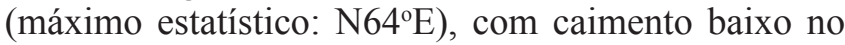
rumo NE (máximo: $6^{\circ}$ ), caracterizando-se geometricamente, em relação à foliação, como uma lineação direcional (Fig. 3B).

Nos setores em que a deformação é menos intensa, observa-se uma estrutura planar subhorizontal anterior que é deformada pelas zonas de cisalhamento subverticais. Nesses locais, ocorrem dobras com superfícies axiais subparalelas às paredes das zonas de cisalhamento com eixos de caimento baixo para NE. 


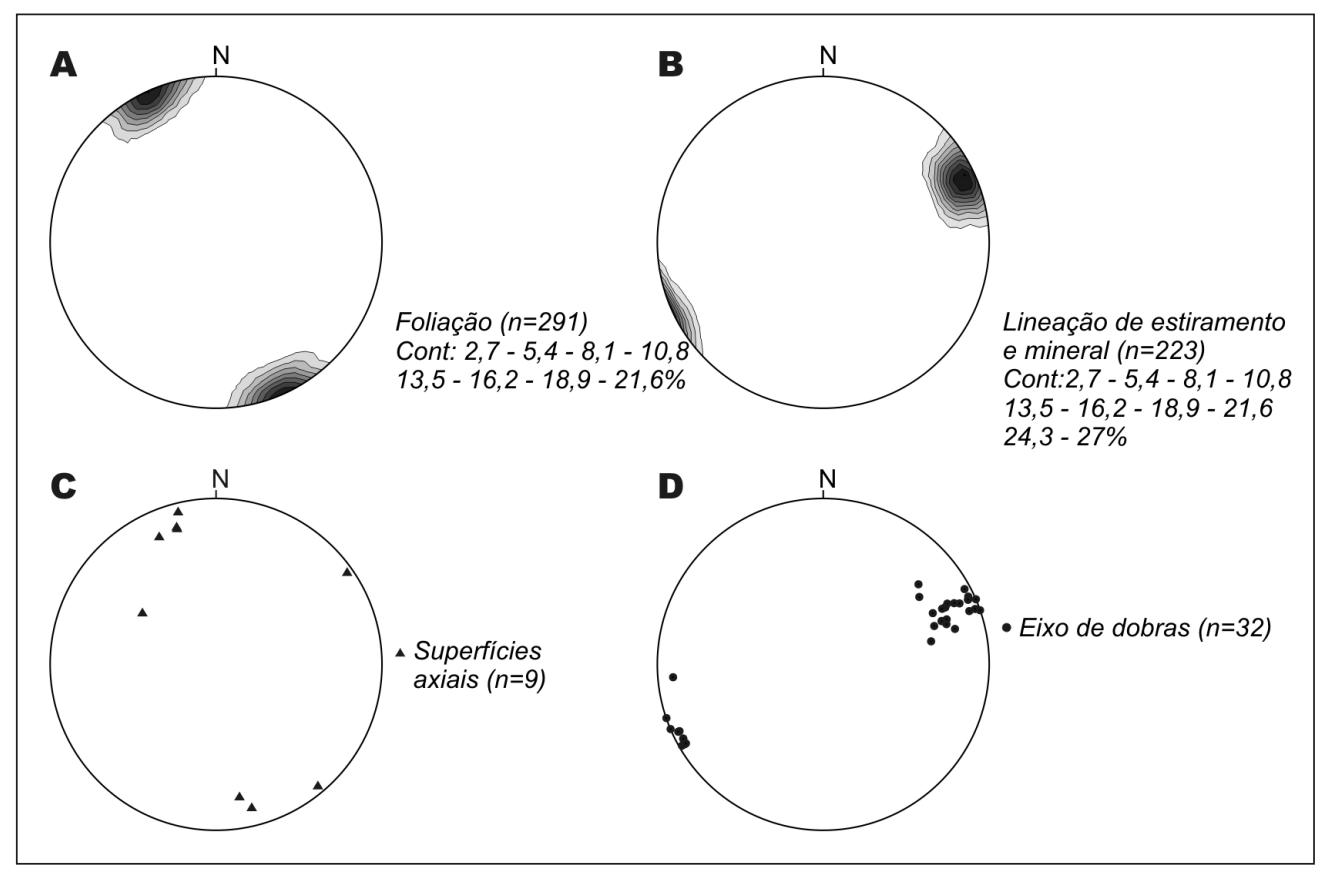

Figura 3 - Diagramas de projeção estereográfica (hemisfério inferior) dos elementos estruturais do Domínio Estrutural I (DE I) da Seção Três Rios - Matias Barbosa (STMB). A-Foliações medidas ao longo da STMB; B-Idem, para lineações; C-Superficie axial das dobras; D-Eixo das dobras. Para detalhes: ver discussão no texto.

São dobras simétricas, caracterizadas por perfis abertos a fechados, localmente isoclinais nas porções mais deformadas.

A foliação milonítica é plano-axial à estas dobras, e os eixos são sub-paralelos à lineação de estiramento mineral e de interseção. Em projeção estereográfica, os eixos destas estruturas são subhorizontais, de orientação geral $\mathrm{N} 64^{\circ} \mathrm{E}$, com superfícies axiais de direção NE-SW e mergulhos subverticais (Figs. 3D e C).

O domínio é caracterizado por uma foliação milonítica subvertical e lineação de estiramento horizontal, situação esta característica de zonas de cisalhamento com movimentação essencialmente direcional.

Os indicadores cinemáticos do domínio (porfiroclastos de feldspato com caudas assimétricas, sistemas de clastos tipo $\sigma$ e $\delta$, tramas compostas com superfícies S-C e inclusões rígidas rotacionadas), observados em plano horizontal, são compatíveis com movimentação destral (Fig. 7A).

Observam-se nos afloramentos dos milonitos boudins estirados em duas direções, vertical e horizontal, do tipo tablete-de-chocolate (Fig. 7B) que, juntamente com os S-tectonitos descritos, sugerem forte achatamento ortogonal ao plano de cisalhamento.

No DE I ocorre uma amplificação cinemática vertical das dobras que é acompanhada da diminuição progressiva do seu ângulo interflancos com as proximidades de zonas de cisalhamento, juntamente com a colocação de diques subhorizontais de leucogranitos (ver Dehler \& Machado 2002), sugerindo encurtamento horizontal ortogonal ao plano de cisalhamento e estiramento vertical, subordinado. Rosier (1957) atribuiu este forte achatamento das dobras à translação para NW das nappes relacionadas a Serra dos Órgãos. Em regiões de alta deformação são encontrados ultramilonitos e a simetria das estruturas é ortorrômbica e a trama é fortemente planar. Os dados estruturais (geométricos, cinemáticos e microtexturais) discutidos neste trabalho reforçam as proposições já apresentadas quanto à estruturação da zona de cisalhamento de Além-Paraíba (Dayan \& Keller 1989, Dayan et al. 1993, Corrêa Neto et al. 1993, Egydio Silva \& Mainprice 1999, Nummer 2001).

Domínio Estrutural II O Domínio Estrutura II (DE II) corresponde ao que tem sido denominado na literatura como Domínio Paraíba (ver Heilbron et al. 1995, Silva et al. 2000). Este domínio corresponde uma "lasca" crustal com mergulho geral para SE, sendo caracterizado por (anfibólio) - biotita ortognaisse acinzentado com sillimanita - granada - biotita gnaisses miloníticos e (anfibólio) - biotita granitóides foliados subordinados. A unidade ortognáissica, de composição granodiorítica a granítica, possui granulação média a grossa. A foliação principal, paralela a um bandamento composicional subhorizontal, pode apresentar ou não textura milonítica. Este bandamento é realçado pela presença de intercalações de níveis quartzo-feldspáticos com níveis máficos, ricos em anfibólio e biotita. A unidade é em geral homogênea e apresenta uma foliação bem pronunciada, definida pela orientação preferencial dos minerais félsicos e máficos, onde é comum a presença de textura porfiroclástica. Ocorrem inclusões/enclaves anfibolíticos e rochas calciossilicáticas, em geral boudinados. As primeiras apresentam dimensões métricas, e as últimas, 


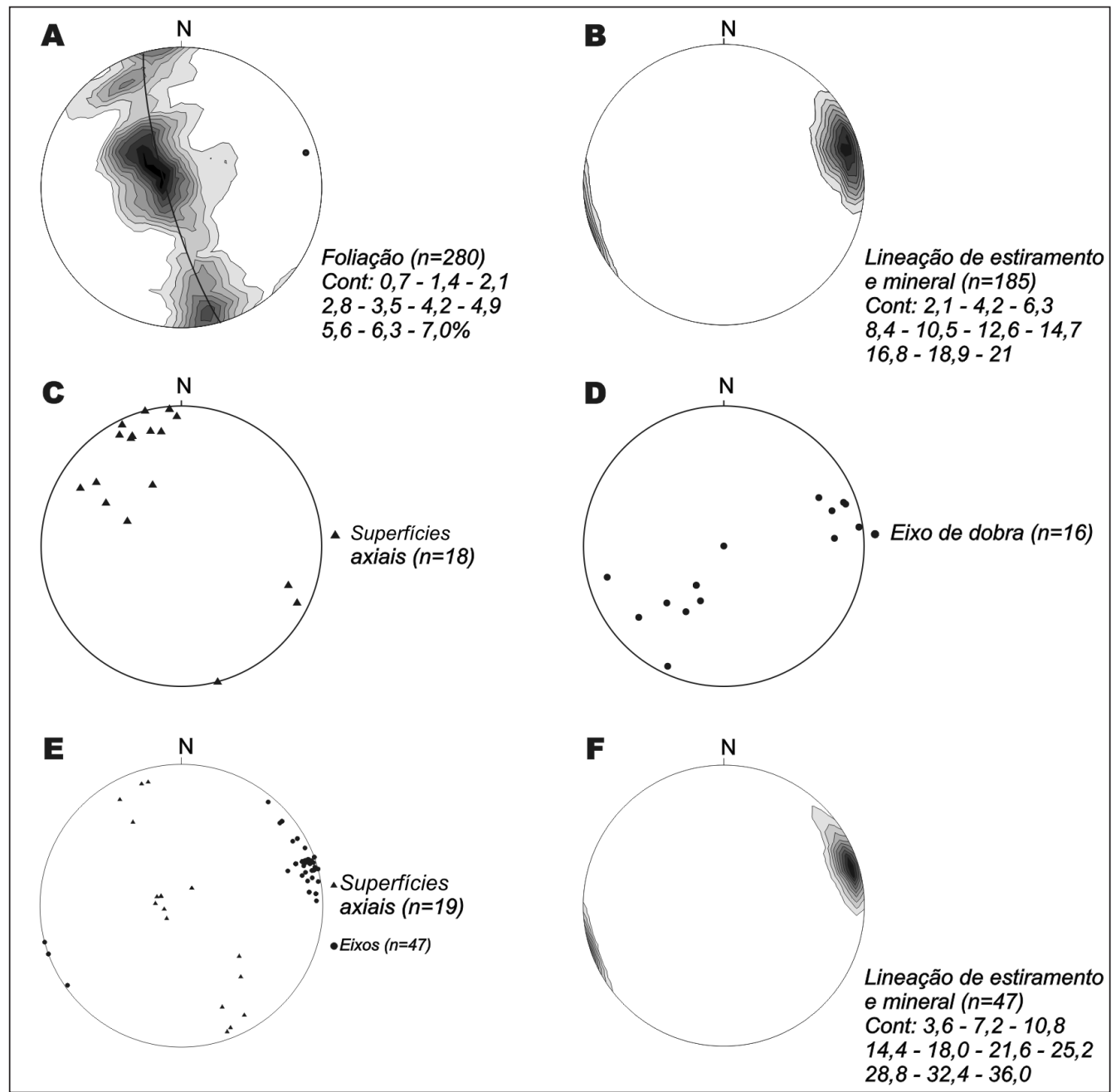

Figura 4 - Diagramas de projeção estereográfica (hemisfério inferior) dos elementos estruturais do Domínio Estrutural II (DE I I) da Seção Três Rios - Matias Barbosa (STMB). A-Conjunto de foliação medidas ao longo da STMB; B-Idem, para lineações; $C$-Superficies axiais de dobras; D- Eixos de dobras; E) Superficies axiais e eixos de dobras de um afloramento ; F) Lineação de estiramento e mineral do mesmo afloramento. Para detalhes: ver discussão no texto.

decimétricas.

A unidade de paragnaisses exibe uma foliação principal subparalela ao bandamento metamórfico, definida pela orientação preferencial dos minerais félsicos e máficos e lentes (ou bandas) de granitos hololeucocráticos e pegmatitos, além de bandas micáceas ricas em biotita e sillimanita. Os corpos graníticos e pegmatíticos são concordantes, subconcordantes e oblíquos à foliação gnáissica. Neste último caso, eles são controlados por zonas de cisalhamento dúcteis tardias. Estes granitos possuem foliação de forma muito pronunciada, caracterizada pela orientação das bordas dos grãos minerais constituintes, que se mostram paralelos a enclaves máficos microgranulares estirados. Em lâmina delgada, o plagioclásio e o K-feldspato mostram-se recristalizados e poligonizados, com deformação das maclas e extinção ondulante dos mesmos, havendo, entretanto, alguns cristais sem evidências de deformação. O quartzo, em contatos lobados, reentrantes e com deformação por migração de borda de grãos, sugere crescimento sob condições de alta temperatura. Alguns cristais apresentam extinção ondulante, enquanto outros não exibem evidências de deformação. Predomina um arranjo granonematoblástico a granolepidoblástico na escala microscópica. A foliação é definida pela orientação preferencial dos minerais máficos (biotita e anfibólio) e bordas de cristais de feldspato e quartzo. Nas porções mais deformadas, a orientação das bordas dos minerais é paralela à estrutura planar diferenciada ou a estrutura do tipo ribbons. A sillimanita ocorre como grãos prismáticos, alongados na foliação principal.

Em projeção estereográfica, a foliação principal possui geometria variável com seus pólos distribuindose segundo um círculo máximo. Nota-se, entretanto, o predomínio de uma foliação com mergulho de baixo ângulo para SE (Fig. 4A). A distribuição dos pólos desta foliação apresenta um máximo principal com atitude $\mathrm{N} 30^{\circ} \mathrm{E} / 12^{\circ} \mathrm{NW}$, e dois secundários: um com atitude $\mathrm{N} 78^{\circ} \mathrm{E} / 81^{\circ} \mathrm{NW}$ e outro, $\mathrm{N} 62^{\circ} \mathrm{E} / 83^{\circ} \mathrm{SE}$. Esta distribuição em guirlanda da foliação principal, juntamente com os 


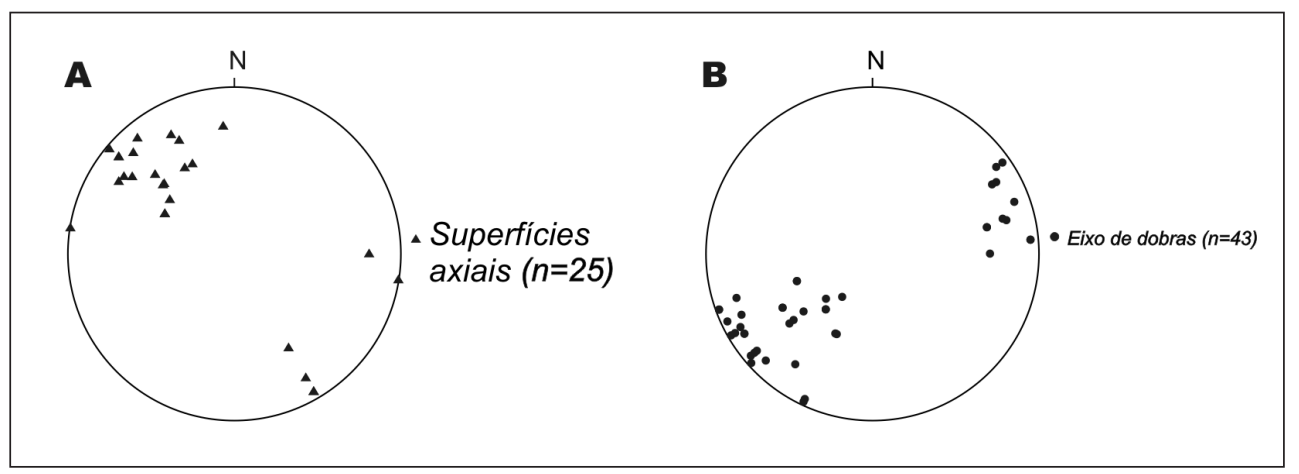

Figura 5 - Projeções estereográficas (hemisfério inferior) dos elementos estruturais de aftoramentos do Domínio Estrutural III (DE III) da Seção Três Rios - Matias Barbosa (STMB). A-Superficies axiais de dobras de um afloramento; B-Idem, para eixos de dobras. Para detalhes: ver discussão no texto.

dados de campo, sugere a existência de segmentos de dobras cilíndricas com eixo de caimento baixo (máximo: $8^{\circ}$ ) para o rumo $\mathrm{N} 74^{\circ} \mathrm{E}$.

As Figuras 4C e 4D representam estereogramas de dobras de um afloramento do DE II. A geometria ilustrada no diagrama é concordante com a da estrutura regional (ver Fig. 4A). No afloramento ocorrem dois grupos de dobras com estilos diferentes: um grupo mais antigo, caracterizado por dobras de perfis fechados a isoclinais, com superfícies axiais subhorizontais (recumbentes) e paralelas à foliação plano-axial, exibindo charneiras espessadas e flancos adelgaçados, por vezes rompidos, cujos eixos mostram-se paralelos a lineação de estiramento e mineral; o segundo grupo de dobras, com perfis abertos a fechados e charneiras arredondadas ou pouco desenvolvidas (agudas), superpõe-se geometricamente às dobras do primeiro grupo. Estas estruturas possuem superfícies axiais subverticais e com direção geral NE-SW. Na Figura 4E encontram-se representados os eixos e superfícies axiais destas estruturas, e na Figura 4F, a lineação de estiramento mineral. Os eixos das dobras, com orientação geral $\mathrm{N} 77^{\circ} / 6^{\circ}$, são subparalelos a lineação de estiramento. Associam-se a estes dois grupos de dobras estruturas lineares como mullions de dobramento.

Nesse domínio, a lineação de estiramento mineral é dada pela orientação preferencial de grãos de quartzo, feldspato, biotita, ou então por agregados destes minerais. Ocorrem corpos graníticos e enclaves máficos microgranulares estirados segundo à lineação e, localmente, L-tectonitos. Apesar da variação mostrada pela geometria da foliação, a lineação de estiramento mineral exibe atitude constante (direção NE-SW), com orientação geral $\mathrm{N} 74^{\circ} \mathrm{E} / 12^{\circ}$ (Fig. 4B), e é subparalela aos eixos das dobras que deformam esta mesma foliação.

As dobras superpostas à trama principal são interpretadas como registros de um componente de encurtamento ortogonal ao plano de foliação principal (Machado 1984, Heilbron 1993). Estas estruturas têm sido consideradas como de implantação tardia às zonas transpressivas de alto ângulo, geradas sob condições metamórficas em fácies anfibolito alto (Heilbron et al. 1995, Almeida 2000) ou em fácies granulito (Egydio Silva et al. 2002), ou então relacionadas à partição da deformação ocorrida em regime transpressivo (Ebert \& Hasui 1998). Dehler \& Machado (2002) descrevem ainda a associação destas estruturas com a intrusão de rochas graníticas na aba sul da divergência estrutural.

No contato com o domínio III são encontradas dobras com geometria diferente daquela descrita ao longo de todo o perfil, cuja superfície dobrada e lineação de estiramento mineral podem ser visualizadas nos diagramas das figuras 4E e 4F. Essas dobras são assimétricas para $\mathrm{N}$ e $\mathrm{W}$, e possuem foliação planoaxial subparalela ao referido contato. Os eixos dessas estruturas estão contidos na superfície axial e variam de paralelos (direção geral NE-SW) a oblíquos à lineação de estiramento (com caimento moderado a localmente íngreme para SW). Cabe salientar que esta variação é local e restrita a este importante contato.

A geometria geral do DII, como mostrado nos estereogramas, sugere a existência de um fragmento crustal com uma estrutura planar dominantemente de baixo ângulo. Esta foliação, entretanto, dispõe-se ao longo de uma guirlanda, cujo eixo coincide com os eixos das dobras tardias identificadas e com a lineação de estiramento no domínio, sugerindo que a direção do movimento principal durante o cisalhamento dúctil tenha sido paralela ao eixo da referida guirlanda e também das dobras tardias. As estruturas monoclínicas descritas nesse domínio são pares de foliações S-C e bandas de cisalhamento assimétricas (Fig. 7 C), porfiroclastos assimétricos do tipo $\delta$ e boudins assimétricos de leucogranitos rotacionados (Figs. $7 \mathrm{D}$ e E). Estas estruturas foram descritas segundo planos XZ do elipsóide de deformação, sendo demarcadas no campo com base numa forte lineação de estiramento mineral. Estes indicadores são consistentes entre si e sugerem durante a deformação principal uma movimentação de topo para SW. As estruturas tardias, superpostas à trama dúctil principal, manifestam-se como zonas de cisalhamento dúcteis discretas e dobras com superfície axial vertical. As zonas de cisalhamento pertencem a dois grupos 
principais: (1) zonas de cisalhamento com mergulho íngreme para SSE e movimentação sinistral com componente de abatimento do bloco S. São estruturas que podem alcançar dimensões métricas e geram muitas vezes dobras de arrasto expressivas na foliação principal; (2) zonas de cisalhamento com mergulho baixo para SE, associadas com planos discretos que podem conter ou não uma lineação de alto rake, caracterizada por uma rugosidade grossa. Estas zonas de cisalhamento podem associar-se a dobras levemente assimétricas para N. A presença de steps e dobras assimétricas associadas sugerem para estas estruturas movimentação de topo para NW. Ambas as zonas de cisalhamento controlam a colocação de mobilizados leucograníticos.

Domínio Estrutural III O Domínio Estrutural III (DE III) corresponde ao domínio tectônico Juiz de Fora de Heilbron et al. (1995). Este domínio encontra-se estruturalmente sotoposto ao DE II, correspondente ao domínio Paraíba do Sul.

Engloba uma associação de ortognaisses e paragnaisses que pode alcançar a fácies granulito. Localmente é marcante o aspecto milonítico destas rochas. Os granulitos podem ou não apresentar um bandamento pronunciado. Ocorrem associados com granada charnockitos foliados e paragnaisses migmatizados. Observam-se, localmente, relações magmáticas anteriores ao metamorfismo regional, com granulitos félsicos ou charnockitos homogêneos sendo intrusivos em gnaisses granulíticos, ou então englobando enclaves de granulitos máficos (ver também Heilbron et al. 1997). Estas rochas intercalam-se em ortogranulitos e anfibólio-biotita gnaisse cinzento (localmente róseo), de composição tonalítica a granítica, mostrando estrutura planar bem pronunciada e textura porfiroclástica, com anfibólio e feldspato estirados. Os paragnaisses possuem foliação paralela a um bandamento composicional bem marcado. Contêm localmente granada, cordierita, sillimanita e hiperstênio. Mostram-se às vezes mais homogêneos, com a foliação tectônica sendo definida pela orientação preferencial de feldspatos estirados. Em lâmina delgada, observa-se amplo desenvolvimento de microestruturas de alta temperatura como feições de recristalização por migração de borda de grãos, crescimento exagerado de cristais de quartzo, deformação dúctil e recristalização de feldspatos, além de ribbons de feldspato alcalino e quartzo.

Uma descrição petrográfica pormenorizada dos granulitos, envolvendo feições microtectônicas e relações texturais entre os seus diversos minerais constituintes, pode ser encontrada em Oliveira (1980, 1981), Duarte (1998), dentre outros.

A foliação principal do DE III apresenta direção geral NE-SW e mergulhos moderados a altos para SE. Nos diagramas, os pólos da foliação concentram-se em $\mathrm{N} 344^{\circ} / 24^{\circ}$ e apresentam atitude estatística N74 ${ }^{\circ} \mathrm{E} / 66^{\circ} \mathrm{SE}$ (Fig. 6 A). Notam-se variações no mergulho da foliação, compatíveis com padrões em leques de foliação ou de estruturas-em-flor positiva. Nota-se ainda que esta foliação é plano-axial de dobras com eixo de caimento suave para ENE.

A lineação de estiramento e mineral é materializada pela orientação de feldspatos, quartzo ou então de minerais hidratados como anfibólio e biotita. Esta estrutura é pouco evidente nos afloramentos desse domínio, tanto naqueles onde predominam tectonitos-S, quanto naqueles em que não é evidente a estrutura dos granulitos. Em projeção estereográfica, os dados da lineação concentram-se no setor NE do estereograma (máximo estatístico: $\mathrm{N} 82^{\circ} \mathrm{E} / 24^{\circ}$ ), exibindo variações de caimento ou rake, podendo mesmo mudar de quadrante, conforme pode ser observado no diagrama da figura $6 \mathrm{~B}$. Não é claro ainda o significado dessas variações, havendo a necessidade de estudos com maior detalhe. A relação geométrica dessa estrutura com a foliação permite classificá-la como uma lineação levemente oblíqua.

As dobras desse segmento apresentam em geral superfícies axiais de direção NE-SW, com mergulhos altos e eixos de caimento suave na mesma direção, mostrando-se localmente com relativa dispersão (Figs. $5 \mathrm{~A}$ e $5 \mathrm{~B}$ ). São dobras de perfis abertos a fechados, localmente isoclinais, com charneiras espessadas e pouco desenvolvidas.

A análise cinemática desse domínio é dificultada por fatores como a homogeneidade litológica dos afloramentos, a deformação relativamente baixa e o predomínio de uma forte trama planar sobre a trama linear nas principais zonas de cisalhamento encontradas.

As estruturas monoclínicas observadas (tramas S-C de foliação, boudins rotacionados, estruturas sigmoidais e, com menor confiabilidade, dobras assimétricas) sugerem movimento de topo para WSW, com movimentação destral em plano horizontal.

Em alguns afloramentos de granulitos observam-se planos de movimentos discretos, dúcteis, associados a uma lineação fina, com movimento de topo para $\mathrm{W}$, compatível com o movimento observado nas zonas de cisalhamento principais (Fig. 7 F). Estes movimentos são sugeridos a partir do deslocamento de marcador planar (seção de observação ortogonal à interseção entre o marcador e a zona de cisalhamento). Ao longo destas estruturas ocorre uma hidratação dos granulitos.

$\mathrm{Na}$ parte sul do domínio, próximo ao contato com o domínio II, ocorre em paragnaisses dobras com charneiras espessadas e eixos girados na direção da lineação de estiramento, sugerindo a existência de dobras em bainha. Para norte, a presença de padrões de foliação com disposição em leque, configurando estruturasem-flor positivas, sugere deformação em regime transpressivo. A existência de uma lineação de estiramento com rake intermediário para NE é compatível com movimentos também oblíquos neste domínio, embora, do ponto de vista mecânico, sejam esperados movimentos mais do tipo direcional.

Regimes Tectônicos e Evolução Estrutural Os dados estruturais aqui apresentados são consistentes com os de trabalhos anteriores (ver Dehler \& Machado 2002), tanto em termos da superposição geométrica 


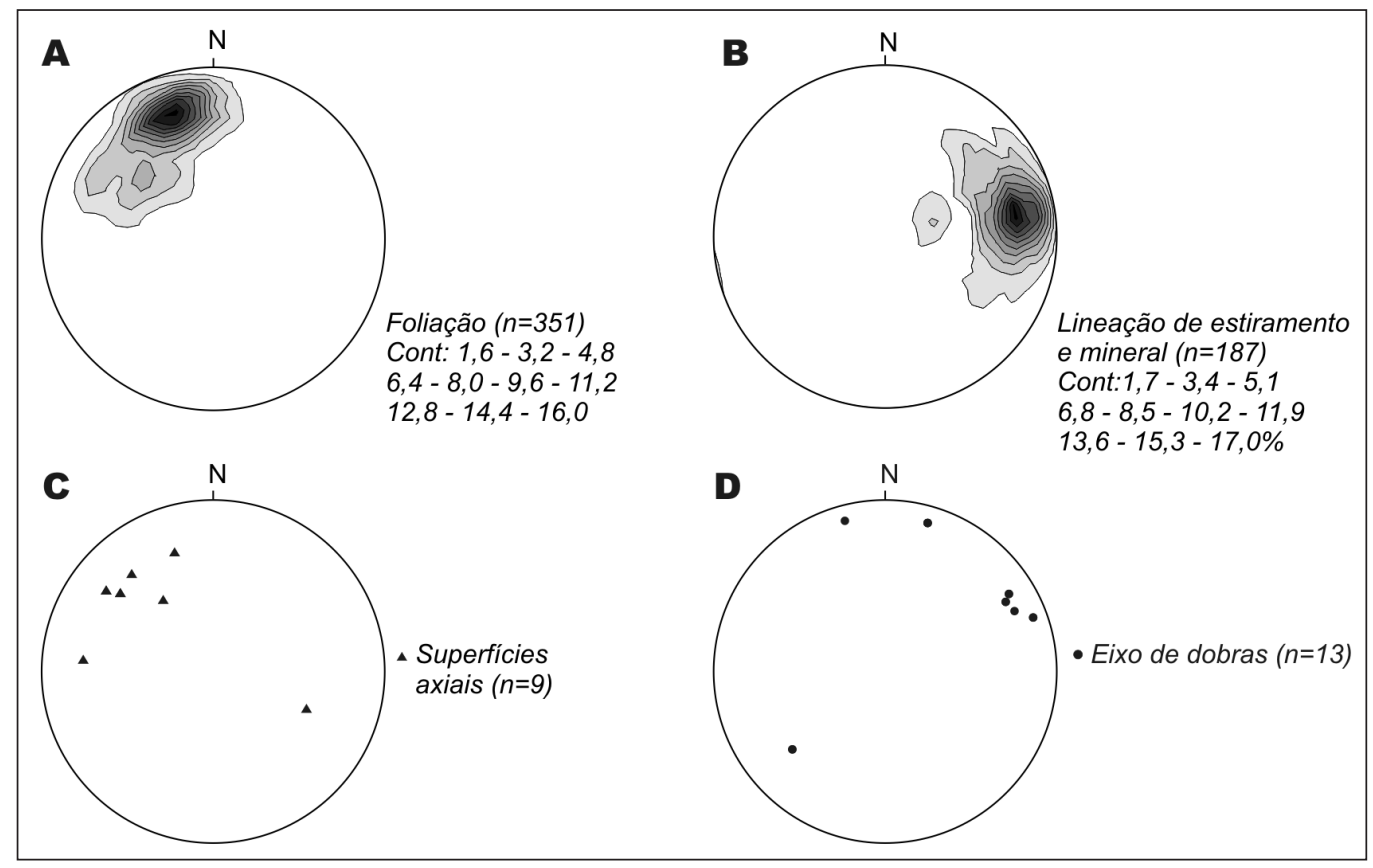

Figura 6 - Diagramas de projeção estereográfica (hemisfério inferior) dos elementos estruturais do Domínio Estrutural III (DE III) da Seção Três Rios - Matias Barbosa (STMB). A-Conjunto de foliação medidas ao longo da STMB; B-Idem, para lineações; C-Superficie axial de dobras; D-Eixo de dobras. Para detalhes: ver discussão no texto.

das estruturas como em relação à cinemática da deformação dúctil principal ativa em condições metamórficas de alto grau. Esses dados são também consistentes com o modelo de transpressão destral, não-confinada. Este modelo, previsto para um mesmo regime regional de deformação, contempla importantes movimentos de massa acomodados em planos de cisalhamento subhorizontais com movimentos paralelos a oblíquos ao trend orogênico (extrusão oblíqua/lateral). Tais movimentos são considerados concomitantes e associados geneticamente ao componente de encurtamento ortogonal ao orógeno.

A análise geométrica e cinemática das estruturas na seção estudada sugere a presença de dois estágios cinemáticos principais: um mais novo, caracterizado por regime transpressivo com componente direcional destral; e outro mais antigo caracterizado por movimento tangencial subparalelo ao CPS na região. O movimento mais antigo ocorreu em condições metamórficas de alto grau, e foi dirigido para WSW, com cinemática regional destral em relação à massa cratônica localizada a norte, a Placa Sanfranciscana (Dehler 2002). Por outro lado, os movimentos tardios teriam ocorrido sob condições mais drásticas de metamorfismo, em regime transpressivo, com partição da deformação em componentes coaxial (dobras e demais estruturas contracionais) (Ebert \& Hasui 1998) e não-coaxial (destral, concentrados nas zonas de cisalhamento de alto ângulo).

São descritos na literatura movimentos tangenciais paralelos ao trend orogênico, instalados em ambiente colisional oblíquo, de forma análoga ao que foi caracterizado no presente artigo no CPS (Ellis \& Watkinson 1987, Vauchez et al. 1993, Northrup \& Bur- chfiel 1996, dentre outros). No CPS, estes movimentos foram atribuídos à extrusão tectônica longitudinal resultante de colisão oblíqua ocorrida durante o Neoproterozóico (Dehler 2002).

Em resumo, os dados aqui discutidos são coerentes com os apresentados para o flanco sul da divergência estrutural (Dehler \& Machado 2002). Além disso, os autores sugerem a existência de uma fase inicial com movimento de topo para SW, resultante de extrusão tectônica oblíqua durante transpressão ocorrida no CPS (transpressão não-confinada). Estas estruturas são superpostas por zonas de cisalhamento dúcteis transpressivas destrais, zonas de cisalhamento inversas, dobras com eixos subhorizontais e superfícies axiais verticais. As zonas de cisalhamento transtrativas têm sido atribuídas ao colapso gravitacional tardio do orógeno (Heilbron et al. 1995). As observações efetuadas no presente trabalho não permitem considerações adicionais sobre a gênese destas estruturas, em função da complexidade que envolve a deformação extensional em cinturões orogênicos, notadamente sua relação com a deformação convergente regional (ver p.ex: Dewey et al.1988 e Doglioni 1996). Contudo, trabalhos recentes realizados na extremidade sul do CPS, na divisa de São Paulo com o Paraná, consideram que condições compressivas e transtrativas podem coexistir durante convergência num modelo de transpressão não-confinada (Dehler et al. 2007).

CONCLUSÕES As estruturas caracterizadas na aba norte da estrutura divergente do rio Paraíba do Sul sugerem um modelo evolutivo de deformação estrutural em dois estágios principais: um mais antigo, envolven- 


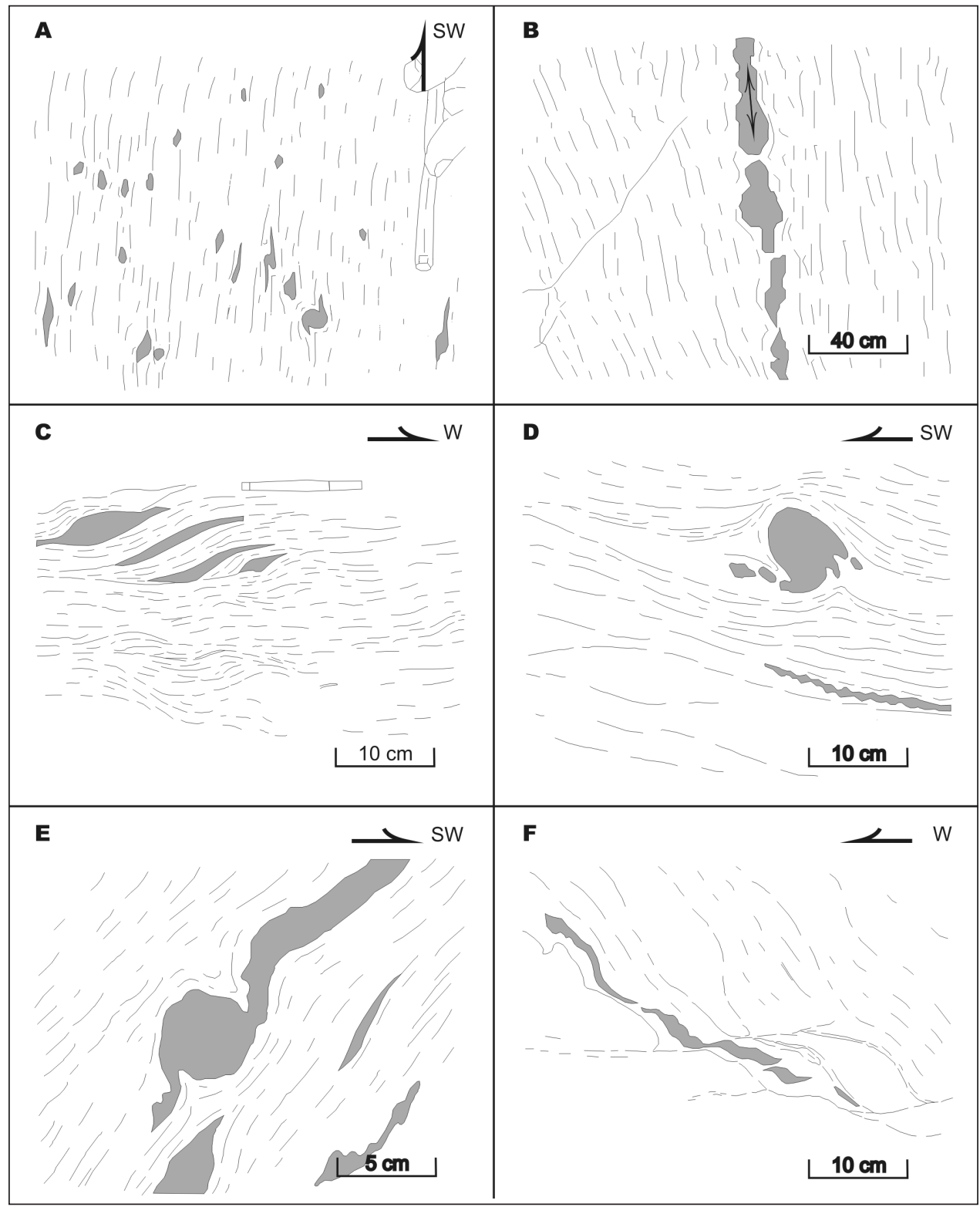

Figura 7 - Estruturas indicativas do sentido de cisalhamento: A-porfiroclastos de feldspatos assimétricos (plano de observação: horizontal); B- boudins estirados na direção vertical ( plano de observação: vertical); $C$ - Pares $S$ - $C$ de foliações $e$ bandas de cisalhamento extensionais (plano de observação: vertical); $D$ - boudin assimétrico de granada rotacionado (plano de observação: vertical) ; E- boudin assimétrico de leucogranito rotacionado (plano de observação: vertical); F- Zonas de cisalhamento discretas subhorizontais (plano de observação: vertical). O sentido de movimento está indicado nas figuras. Para detalhe: ver discussão no texto.

do movimento tangencial de topo para WSW, sob condições metamórficas de alto grau, responsável pelo emplacement oblíquo de um fragmento crustal (infracrustal) relativo ao Domínio II, correspondente ao Domínio Paraíba do Sul. Este estágio foi acompanhado pela extrusão tectônica para SW, em regime transpressivo, de fragmentos da crosta média/inferior das porções internas do Cinturão Paraíba do Sul na região. Durante este estágio, o cisalhamento não-coaxial subhorizontal produziu o giro das dobras internas para uma posição paralela a lineação de estiramento mineral. Esse movimento é compatível com a existência de empurrões oblíquos ao longo de planos de cisalhamento orientados NE-SW (topo para NW e componente direcional destral), descritos em diversos pontos do CPS; com o progresso da convergência oblíqua, a foliação subhorizontal anterior é afetada por dobras tardias, com eixos subparalelos à direção de movimento, zonas de cisalhamento transpressivas subverticais e zonas de cisalhamento inversas, dando origem às estruturas do estágio mais jovem. Ambas as famílias de estruturas são cinematicamente compatíveis, sugerindo sua coexistência durante pelo 
menos parte do período considerado da evolução tectônica do CPS. Num estágio mais avançado da convergência, as dobras tornam-se mais apertadas, favorecendo o movimento em zonas subverticais, e também de empurrões discretos. Zonas dúcteis extensionais, locais e discretas, deformam a estruturação principal, e encontram-se aparentemente desvinculadas do evento deformacional regional aqui descrito.

Os dados aqui apresentados, juntamente com os disponíveis na literatura (ver p.ex. Heilbron 1993), sugerem que os incrementos tardios da deformação principal tenham ocorrido pelo menos sob condições de fácies anfibolito alto, promovendo a hidratação generalizada dos granulitos ao longo de planos de movimentos discretos.

Finalmente, os dados estruturais discutidos su- portam para o segmento do CPS no Rio de Janeiro a existência de uma movimentação principal subparalela a oblíqua ao referido cinturão na região. Considerandose a Placa Sanfranciscana como referência (ver Dehler 2002), nota-se que esta movimentação é compatível com o deslocamento regional destral do Cinturão com relação à referida placa.

Agradecimentos Os autores agradecem à CPRM Serviço Geológico do Brasil, pelo apoio - durante e após - para a realização das atividades de campo, agradecem também à FAPESP (Proc. 02/12601-4), pelo suporte financeiro que permitiu a realização de parte dos trabalhos de campo, e, finalmente, ao CNPq (Proc. 300423/82-9, de R. Machado), pela concessão de uma bolsa de Produtividade em Pesquisa.

\section{Referências}

Almeida F.F.M., Amaral G., Cordani U.G., Kawashita K. 1973. The precambrian evolution of the South American cratonic margin south of Amazon river. In: E.M. Nairn \& F.G. Stehli (eds.) The Ocean Basins and Margins. New York, Plenun, p. 411-446.

Almeida F.F.M., Hasui Y., Carneiro C.D.R. 1975. O lineamento de Além-Paraíba. Anais Acad. Bras. Ciênc., 48:575.

Almeida J.C.H. 2000. Zonas de cisalhamento dúcteis de alto grau do Médio Vale do Rio Paraíba do Sul. Tese de Doutoramento, Instituto de Geociências e Ciências Exatas, Universidade Estadual Paulista, 190p.

Campanha G. 1981. O lineamento de Além-Paraíba na área de Três Rios, RJ. Rev. Bras. Geoc. 11:159-171.

Chauvet A. \& Séranne M. 1994. Extension-parallel folding in the Scandinavian Caledonides: implications for lateorogenic processes. Tectonophysics, 238:31-54.

Corrêa Neto A.V., Dayan H., Valença J.G., Rafael Cabral A. 1993. Geologia e estrutura da zona de cisalhamento do rio Paraíba do Sul entre Três Rios, RJ e Sapucaia, RJ. In: SBG, Simp. Geol. Sudeste, 3, Atas, p. 194-200.

Dayan H. \& Keller J.V.A. 1989. A zona de cisalhamento do Rio Paraíba do Sul nas vizinhanças de Três Rios, RJ: uma análise da deformação dada por algumas feições estruturais. Rev. Bras. Geoc., 19:494-506.

Dayan H., Corrêa Neto A.V., Valença J.G. 1993. A zona de cisalhamento do Rio Paraíba do Sul: Estudo de Padrões de orientação preferencial de eixos-c de quartzo. In: SBG, Simp. Nac. Est. Tect., 4, Anais, p. 339-342.

Dehler N.M. 2002. Extrusão tectônica oblíqua em regime transpressivo no Cinturão Paraibides, RJ. São Paulo, Tese de Doutoramento, Instituto de Geociências, Universidade de São Paulo, 161p.

Dehler N.M. \& Silva P.C.S. 2000. Projeto compilação geológica da Folha Volta Redonda (escala 1:250.000). São Paulo, CPRM, 16p. (Nota Explicativa).

Dehler N.M. \& Machado R. 2002. Análise Cinemática da aba sul da estrutura divergente do Rio Paraíba do Sul, na porção ocidental do estado do Rio de Janeiro. Rev. Bras. Geoc., 32:481-490.
Dehler N.M., Machado R., Fassbinder E. 2007. Shear structures in the Serra do Azeite shear zone, Southeastern Brazil: transtensional deformation during regional transpression in the Central Mantiqueira Province (Ribeira belt). Journ. South Am. Earth Sc., 23:176-192.

Dehler N.M., Machado R., Dehler H.R.S., Nummer A., Fassbinder E. 2004. Orogenic-parallel tangential shearing in convergent orogens: transient strain accommodating parallel flow during transpression and extrusion in the Paraíba do Sul belt, southeastern Brazil. In: Inter. Geol. Congr., 32, Abstracts, p. 96-1.

Dewey J.F., Holdsworth R.E., Strachan R.A. 1998. Transpression and transtension zones. In: R.E. Holdsworth, R.A. Strachan, J.F. Dewey (eds). Continental Transpressional and Transtensional Tectonics. London Geological Society, Special Publication, 135, p. 1-14.

Doglioni C. 1996. Geological remarks on the relationships between extension and convergent geodynamic settings. Tectonophysics 252:253-267.

Duarte B.P. 1998. Evolução tectônica dos ortognaisses dos complexos Juiz de Fora e Mantiqueira na região de Juiz de Fora, MG: geologia, petrologia e geoquímica. São Paulo, Tese de Doutoramento, Instituto de Geociências, Universidade de São Paulo, 280p.

Ebert H. 1968. Ocorrências de fácies granulíticas no sul de Minas Gerais e em áreas adjacentes em dependência da estrutura orogênica: hipóteses sobre sua origem. An. Acad. Bras. Ciênc., 40:215-229.

Ebert H. 1984. Os Paraibides entre São João del Rei, Minas Gerais, e Itapira, São Paulo, e a bifurcação entre Paraibides e Araxaides. Public. Soc. Bras. Geol. SP, Documento, 12:72-103.

Ebert H.D. \& Hasui Y. 1998. Transpressional tectonics and strain partitioning during oblique colision between three plates in the precambrian of south-east Brazil. In: R.E. Holdsworth, R.A. Strachan, J.F. Dewey (eds.) Continental transpressional and transtensional tectonics. London Geological Society, Special Publication,135,p. 231-252.

Ebert H.D., Hasui Y., Costa J.B.S. 1991. O caráter transpressivo do cinturão transcorrente rio Paraíba do Sul. In: 
SBG, Simp. Nac. Est. Tect., 3, Boletim de Resumos Expandidos, p. 139-141.

Ebert H.D., Hasui Y., Sartorato G., Almeida S.H., Costa J.B.S. 1993 a. Arcabouço estrutural e tectônica transpressiva das faixas móveis da borda sul e sudeste do cráton do São Francisco e da Sintaxe de Guaxupé. In: SBG, Simp. Nac. Est. Tect., 4, Anais, p. 166-171.

Ebert H.D., Neves M.A., Hasui Y., Szatmari P., Aires J.R. 1993 b. Evolução dos cinturões de cisalhamento entre os blocos São Paulo, Vitória e Brasília através da tectônica colisional oblíqua - uma modelagem física. In: SBG, Simp. Nac. Est. Tect., 4, Anais, p. 254-258.

Egydio-Silva M. \& Mainprice D. 1999. Determination of stress directions from plagioclase fabrics in high grade deformed rocks (Além-Paraíba shear zone, Ribeira fold belt, southeastern Brazil). Journ. Struc. Geol., 21:17511771.

Egydio-Silva M., Vauchez A., Bascou J., Hippert J.F. 2002. High temperature deformation in the neoproterozoic transpressional Ribeira Belt, southeast Brazil. Tectonophysics, 352:203-224.

Egydio-Silva M., Vauchez A., Raposo M.I.B., Jérome B., Uhlein A. 2004. Anisotropia de suscetibilidade magnética aplicada à análise tectônica em granulitos da faixa Ribeira(SE Brasil).In:SBG, ong.Bras.Geol.,42, Atas,cd

Ellis M. \& Watkinson A.J. 1987. Orogen-parallel extension and oblique tectonics: The relation between stretching lineations and relative plate motions. Geology, 15:10221026.

Hanmer S. \& Paschier C. W. 1990. Shear Sense Indicators: a review. Geological Survey of Canada Paper, 90-17,72 p.

Hasui Y. \& Oliveira M.A.F. 1984. A Província Mantiqueira - Setor Central. In: F.F.M. Almeida \& Y. Hasui (eds.) $O$ Pré-Cambriano do Brasil, São Paulo, Edgard Blücher, p.308-344.

Heilbron M. 1993. Evolução Tectônico-metamórfica da seção Bom Jardim de Minas (MG)-Barra do Piraí (RJ). Setor central da Faixa Ribeira. São Paulo, Tese de Doutoramento, Instituto de Geociências, Universidade de São Paulo, 268p.

Heilbron M., Machado R., Figueiredo M.C.H. 1997. Lithogeochemistry of Paleoproterozoic Orthogranulites from the Rio Preto (MG) - Vassouras (RJ) region, central Ribeira Belt, SE Brazil. Rev. Bras. Geoc., 27: 83-98.

Heilbron M., Valeriano C.M., Almeida J.C.H., Tupinambá M. 1991. A Megassinformal do Paraíba do Sul e sua implicação na compartimentação tectônica do setor central da Faixa Ribeira. In: SBG, Simp. Geol. Sudeste, 2, Atas, p. 519-527.

Heilbron M., Valeriano C.M., Valladares C.S., Machado N. 1995. A orogênese brasiliana no segmento central da Faixa Ribeira, Brasil. Rev. Bras. Geoc., 25:249-266.

Heilbron M., Pedrosa Soares A.C., Campos Neto M.C., Silva L.C, Trouw R.A.J., Janasi V.A. 2004. Província Mantiqueira. In: V. Mantesso-Neto, A. Bartorelli, C.D.R. Carneiro, B.B. Brito Neves (org.) Geologia do continente sul-americano, Beca, p. 203-235.

Machado R. 1983. Considerações sobre a estruturação tectônica divergente da porção ocidental do Estado do Rio de Janeiro. In: SBG, Simp. Reg. Geol., 4, Atas: p.135-145.
Machado R. 1984. Evolução Geológica, Análise Estrutural e Metamórfica da Região de Vassouras e Paracambi, Porção Ocidental do Estado do Rio de Janeiro. São Paulo, Tese de Doutoramento, Instituto de Geociências, Universidade de São Paulo, 196p.

Machado R. \& Endo I. 1993 a. Cinturão de Cisalhamento Atlântico: um exemplo de tectônica transpressiva neoproterozóica. In: SBG, Simp. Nac. Est. Tect., 4, Atas, p. 189-191.

Machado R. \& Endo I. 1993 b. Megaestrutura em flor positiva do vale do Rio Paraíba do Sul no Rio de Janeiro e suas implicações tectônicas regionais. In: SBG, Simp. Geol. Sudeste, 3, Atas, v. 1, p. 208-213.

Northrup C.J. \& Burchfiel B.C. 1996. Orogen-parallel transport and vertical partitioning of strain during oblique collision. Journ. Struc. Geol., 18:1231-1244.

Nummer A.R. 2001. Geometria e cinemática de alojamento do Maciço Granítico Arrozal, sudoeste do estado do Rio de Janeiro. São Paulo, Tese de Doutoramento, Instituto de Geociências, Universidade de São Paulo, 169 p.

Oliveira M.A.F. 1980. Petrologia das rochas granuliticas da Faixa Paraíba do Sul, Estados do Rio de Janeiro e Minas Gerais. Tese de Livre-Docência, Instituto de Geociências e Ciências Exatas, Universidade Estadual Paulista, 116 p.

Oliveira M.A. F. 1981. Granulitos da faixa Paraiba do Sul: caracteres químicos dos piroxênios e valores geotermobaromérticos. Rev. Bras. Geoc., 11:222-226.

Rosier G.F. 1957. A geologia da Serra do Mar entre os picos da Maria Comprida e do Desengano. Boletim da Divisão de Geologia e Mineralogia, 166 p.

Rosier G.F. 1965. Pesquisas geológicas na parte oriental do Estado do Rio de Janeiro. Boletim da Divisão de Geologia e Mineralogia, $222 \mathrm{p}$.

Silva L.C., Santos, R.A, Delgado, I.M., Cunha, H.C. (Coords.) 2000. Mapa Geológico do Estado do Rio de Janeiro. Rio de Janeiro, CPRM/DRM, escala 1: 400.000.

Simpson C. \& Schmid S.M. 1983. An evaluation of criteria to deduce the sense of movement in sheared rocks. Geological Society of America Bulletim, 94:1281-1288.

Teyssier C., Tikoff B., Markley M. 1995. Oblique plate motion and continental tectonics. Geology, 23:447-450.

Tikoff B. \& Teyssier C. 1994. Strain modeling of displacement-field partitioning in transpressional orogens. Journ. Struc. Geol., 16:1575-1588.

Trouw R.A.J., Heilbron M., Ribeiro A., Paciullo F.V.P., Valeriano C.M., Almeida J.C.H., Tupinambá M., Andreis R. 2000. The central segment of the Ribeira Belt. In: U.G. Cordani, E.J. Milani, A. Thomaz Filho, D.A. Campos (eds.) Tectonic Evolution of South America, Rio de Janeiro, p. 287-310.

Turner F.J. \& Weiss L.E. 1963. Structural Analysis of Metamorphic Tectonites. New York, McGraw Hill, 545 p.

Vauchez A., Babaie H.A., Babaei A. 1993. Orogen-parallel tangential motion in the Late Devonian-Early Carboniferous southern Appalachians Internides. Canadian Journal of Earth Sciences, 30:12.

Manuscrito A-1579 Aceito em 11 de julho de 2007 